\title{
Analysis of Biochemical Composition of Honey Samples from North-East Nigeria
}

Fatimah Buba*, Abubakar Gidado and Aliyu Shugaba

Department of Biochemistry, Faculty of Science, University of Maiduguri, Nigeria

\begin{abstract}
Natural honey is one of the most widely sought products due to its unique properties, which are attributed to the influence of the different groups of substances it contains. Honey is used for nutritional, medicinal and industrial purposes and it is an important commodity in the international market; serving as foreign exchange earner for many countries. In Nigeria, honey production (beekeeping) has the potential to develop as a prime agro-horticultural and forest-based industry which can be a major foreign exchange earner if international standards are met. The precise chemical composition and physical properties of natural honeys differ according to the plant species on which the bees forage. Differences in climatic conditions and vegetations are also important factors that can affect the various properties of honey. North-eastern Nigeria consists of humid, semi arid and arid climates with varying agricultural activities and blossoms from different types of vegetations, which can influence the natural composition and properties of honey. Thus, analysis of the biochemical composition of 18 honey samples obtained from different locations in the northeast sub-region of Nigeria was carried out to ascertain their qualities. Moisture and ash contents of the samples had average values of $16.00 \pm 2.19 \mathrm{~g} / 100 \mathrm{~g}$ and $0.47 \pm 0.09 \mathrm{~g} / 100 \mathrm{~g}$, respectively. The protein contents ranged between 0.35 and $1.08 \mathrm{~g} / 100 \mathrm{~g}$ with a mean of $0.67 \pm 0.25 \mathrm{~g} / 100 \mathrm{~g}$ while fat content lied between 0.10 and $0.50 \mathrm{~g} / 100 \mathrm{~g}$ with a mean of $0.29 \pm 0.11 \mathrm{~g} / 100 \mathrm{~g}$. Total carbohydrate contents and Energy values showed average values of $82.30 \pm 2.03 \mathrm{~g} / 100 \mathrm{~g}$ and $1,401.33 \pm 33.71 \mathrm{KJ} / 100 \mathrm{~g}$, respectively. Fructose contents gave an average of $38.94 \pm 0.90 \mathrm{~g} / 100 \mathrm{~g}$, while glucose contents had a mean value of $31.65 \pm 2.79 \mathrm{~g} / 100 \mathrm{~g}$. The sucrose contents of the honey samples had a mean value of $1.84 \pm 0.79 \mathrm{~g} / 100 \mathrm{~g}$. Total polyphenol and vitamin C contents showed mean values of $65.31 \pm 19.50 \mathrm{mg}$ Gallic Acid Equivalent (GAE)/100 g and $21.15 \pm 3.99 \mathrm{mg} / 100 \mathrm{~g}$, respectively. The results of this study indicate that the samples compare favorably with samples in many parts of the world and also fall within the limits of international standards.
\end{abstract}

Keywords: Honey; Proximate composition; Sugars; Polyphenol; Vitamin c; International Standards

\section{Introduction}

Natural honey is one of the most widely sought products due to its unique nutritional and medicinal properties, which are attributed to the influence of the different groups of substances it contains. Codex Alimentarius Commission defined honey as the natural sweet substance produced by honey bees, Apis mellifera, from the nectar of plants (blossoms) or from the secretions of living parts of plants or excretions of plant sucking insects on the living parts of plants, which honey bees collect, transform by combining with specific substances of their own, deposit, dehydrate, store and leave in the honey comb to ripen and mature $[1,2]$. The bees are said to produce honey in order to serve as their source of food in times of scarcity or during harsh weather conditions [3].

Essentially, natural honey is a sticky and viscous solution with a content of $80-85 \%$ carbohydrate (mainly glucose and fructose), $15-17 \%$ water, $0.1-0.4 \%$ protein, $0.2 \%$ ash and minor quantities of amino acids, enzymes and vitamins as well as other substances like phenolic antioxidants [3-7]. Each of these minor constituents is known to have distinctive nutritional or medicinal properties and the unique blend accounts for the varied and different applications of natural honeys [3]. Although the major constituents of honey are nearly the same in all honey samples, the precise chemical composition and physical properties of natural honeys differ according to the plant species on which the bees forage [3,8-11]. Furthermore, differences in climatic conditions and vegetations are important factors that can affect the various properties of honey.

Honey is used for nutritional, medicinal and industrial purposes and it is an important commodity in the international market; serving as foreign exchange earner for many countries. Beekeeping is an ageold tradition in Nigeria but it is not considered as a profit making venture in most parts of the country. Thus, while beekeeping has been part of normal agricultural enterprise among some communities in the country $[12,13]$, honey production has largely been at a subsistence level [12-15]. However, honey is found in beehives in large quantities in Nigeria [16] and it has been recognized that honey production (beekeeping) has the potential to develop as a prime agro-horticultural and forest-based industry which can well become a major foreign exchange earner if international standards are met. For instance, it was shown that in Adamawa State, a beekeeper with an average number of 27 beehives made an average of \$1,119.29 per annum from the sales of honey and beeswax [17]. Similarly, it was reported that in Ekiti State, a beekeeper with an average of 20 beehives made average revenue from sales of honey, bees wax and propolis amounting to about $\$ 2,148.42$ per annum and \$1,027.29 per annum for langstroth and topbar hives users, respectively $[18,19]$ had reported that in Adamawa State, only a small percentage $(5.62 \%)$ of the farming population who were already in the practice of beekeeping actually perceived apiculture as a profitable enterprise and know of its profitability; majority (56.25\%) of the rural

*Corresponding author: Fatimah Buba, Faculty of Science, Department of Biochemistry, University of Maiduguri, Nigeria, E-mail: fatimahbuba@gmail.com

Received August 18, 2013; Accepted September 19, 2013; Published September 22, 2013

Citation: Buba F, Gidado A, Shugaba A (2013)Analysis of Biochemical Composition of Honey Samples from North-East Nigeria. Biochem Anal Biochem 2: 139. doi: 10.4172/2161-1009.1000139

Copyright: (C) 2013 Buba F, et al. This is an open-access article distributed under the terms of the Creative Commons Attribution License, which permits unrestricted use, distribution, and reproduction in any medium, provided the original author and source are credited. 
farming community and about $36.25 \%$ of the urban farming community considered apiculture only as a sideline economic activity.

The ecology of Nigeria varies from tropical forest in the south to dry savanna in the far north, yielding a diverse mix of plant and animal life. The northeast sub-region, which lies within $9^{\circ}-14^{\circ} \mathrm{N}$ and $80-150 \mathrm{o}$ is about one fourth (1/4) of the land mass of Nigeria [20] and comprises of six states (Adamawa, Bauchi, Borno, Gombe, Taraba and Yobe States), most of which share boundaries with international communities like Cameroun, Chad and Niger Republics. This sub-region of Nigeria consists of humid, semi arid and arid climates with varying agricultural activities and blossoms from different types of vegetations, which can influence the natural composition and properties of honey in the area; thereby making it very suitable for apicultural practice.

Available literature on the properties and qualities of Nigerian honey have largely focused on samples obtained in the southern parts of the country $[10,21,22]$; with very scarce information on samples obtained in the northern parts, especially the northeast sub-region where commercial beekeeping practice has been documented $[17,19]$. This paper reports on the biochemical properties of honey from northeast Nigeria.

\section{Materials and Methods}

\section{Sample Collection and Preparation}

Eighteen (18) honey samples harvested from different locations in the northeast sub-region were obtained and used for the study. All the samples were collected freshly in sterile containers (labeled with numbers, place and date of collection) and stored at ambient temperature until analyzed. Unwanted material such as wax sticks, dead bees and particles of combs were removed by straining the samples through cheesecloth before analysis.

\section{Biochemical Analysis}

Determination of proximate composition: Proximate compositions of the honey samples were determined using the methods of AOAC (1990; 2000). For moisture content, 2.0g of each sample was dried to constant weight in hot air oven at $70^{\circ} \mathrm{C}$ and the moisture was calculated on dry basis. Ash content was determined by drying $5.0 \mathrm{~g}$ of honey samples in porcelain crucibles at $105^{\circ} \mathrm{C}$ for $3 \mathrm{hrs}$ in hot air oven. The dried samples were ignited in a furnace at $550-600^{\circ} \mathrm{C}$ to constant weight, cooled and weighed. Protein content was determined using the micro-kjeldhal procedure to estimate the total nitrogen content and the protein content was calculated using the 6.25 conversion factor for protein nitrogen.

Crude fat content was determined following extraction using rob ring tube or Majonnier fat extraction apparatus [23]. Five grams (5.0 g) of the honey sample was weighed in the extraction apparatus and mixed thoroughly with $2.0 \mathrm{~mL}$ of $99 \%$ ethyl alcohol. Then $10.0 \mathrm{~mL}$ of dilute $\mathrm{HCl}$ (prepared by adding 11 volumes of water to 25 volumes of concentrated $\mathrm{HCl}$ ) was added and mixed well. The tube was then set in a water bath held at $70-80^{\circ} \mathrm{C}$ and shaken frequently at intervals for 30-40 minutes. The fat extraction apparatus was then filled to half its volume capacity with alcohol and cooled. Twenty five mililitres (25.0 $\mathrm{mL}$ ) of ethyl ether was then added, shaken vigorously and allowed to stand until the upper liquid was practically clear. The ether extract was then drawn off by passing through a filter (using a plug of cotton in the stem of the funnel just enough to allow free passage of ether extract) into a pre-weighed $125 \mathrm{~mL}$ beaker, and was then dried on a water bath. The liquid remaining in the tube was re-extracted twice each with only
$1.0 \mathrm{~mL}$ of ether. A similar pre-weighed beaker was then used as counter poise at $100^{\circ} \mathrm{C}$. The beakers were then cooled in desiccators to constant weight and the fat content calculated.

Carbohydrate contents of the honey samples were determined by calculation (by difference) as follows:

$\%$ Carbohydrate $=100 \%-(\%$ Moisture+\%Crude Fat+\%Crude Protein $+\%$ Ash $)$.

The energy values of the samples were determined by calculation as follows:

Energy $(K J / 100 \quad g)=4.186 \quad[(\%$ Crude Protein $x$ 4) $+(\%$ Crude Fat $x$ 9) $+(\%$ Carbohydrate $x 4)]$

Determination of reducing sugars and sucrose contents: The estimation of reducing sugars was carried out using the Layne-Enyon method as described in AOAC [23]. About $2.6 \mathrm{~g}$ of honey was weighed and transferred to a $500 \mathrm{~mL}$ volumetric flask. Five milliliters $(5 \mathrm{~mL})$ of standardized Fehling's solutions A and B were transferred to a 250 $\mathrm{mL}$ Erlenmeyer flask containing $7.0 \mathrm{~mL}$ of water and $15.0 \mathrm{~mL}$ of honey solution. The Erlenmeyer flask was heated and $1.0 \mathrm{~mL}$ of methylene blue $(0.2 \%)$ was added. Titration was carried out by adding the diluted honey solution until the indicator decolorizes.

Sucrose content was determined by inversion, adding $10 \mathrm{~mL}$ of dilute $\mathrm{HCl}, 50 \mathrm{~mL}$ of diluted honey solution and water in a $100 \mathrm{~mL}$ volumetric flask. The solution was then heated in a water bath, cooled and diluted to the mark. Finally, the Layne-Enyon method was applied and the sucrose content was obtained by difference.

Determination of glucose content: Glucose content of the honey samples was determined by enzymatic oxidation with glucose oxidase reagent (Randox Laboratories Ltd., UK). Twenty microlitres $(20 \mu \mathrm{L})$ of the sample or standard was allowed to react with $2.0 \mathrm{~mL}$ of the reagent, mixed well and incubated for $10 \mathrm{~min}$ at $37^{\circ} \mathrm{C}$. The absorbance of the sample $\left(\mathrm{A}_{\text {sample }}\right)$ and standard $\left(\mathrm{A}_{\text {standard }}\right)$ was read against a reagent blank within $60 \mathrm{~min}$. Glucose concentration was calculated as follows:

$$
\begin{aligned}
\text { Glucose content }(\mathrm{mg} / \mathrm{dL}) & =\left(A_{\text {sample }} / A_{\text {standard }}\right) \times \text { Conc. of standard } \\
& =\left(A_{\text {sample }} / A_{\text {standard }}\right) \times 100(\mathrm{mg} / \mathrm{dL})
\end{aligned}
$$

Determination of fructose content: Fructose content was determined using the resorcinol reagent method [24]. To a solution of the honey sample, $1.0 \mathrm{~mL}$ resorcinol reagent was added and mixed thoroughly, and then $1.0 \mathrm{~mL}$ of dilute $\mathrm{HCl}$ was added. Standard solutions containing $0.2,0.4,0.6,0.8$ and $1.0 \mathrm{mg} / \mathrm{mL}$ and made up to 2 $\mathrm{mL}$ with distilled water was also treated with $1.0 \mathrm{~mL}$ of the resorcinol reagent and $1.0 \mathrm{~mL}$ of diluted $\mathrm{HCl}$ as above. A blank solution was also prepared along with the standard and treated in the same manner. The test solution, the standard and blank were then heated in a water bath at $80^{\circ} \mathrm{C}$ for about $10 \mathrm{~min}$, the solution was then removed from the water bath, cooled by immersing in tap water for $5 \mathrm{~min}$ and then the absorbance of both the test and standard solution were read against the blank solution at $520 \mathrm{~nm}$ within $30 \mathrm{~min}$. The fructose contents of the honey samples were then extrapolated from a standard curve prepared using the absorbance of the standard.

Determination of total phenolic content: The phenolic compounds (flavonoids and phenolic acids) were extracted from the honey samples according to the method described by Kacaniova [25]. Ten grams (10 g) of the honey sample was dissolved in $50 \mathrm{~mL}$ of acidified deionised water (acidified to $\mathrm{pH} 2$ with $\mathrm{HCl}$ ). The solution was then filtered with a cotton filter to remove solid particles and the filtrate was used 
for the estimation of total phenolic compounds. The total phenolic content was estimated using the Folin-Cioucalteu colorimetric method. Appropriately diluted honey sample, $0.2 \mathrm{~mL}$ of $10 \%$ aqueous extract of the honey sample was treated with $0.8 \mathrm{~mL}$ of the Folin-Cioucalteu reagent and $2.0 \mathrm{~mL}$ of $7.5 \% \mathrm{Na}_{2} \mathrm{CO}_{3}$. The mixture was diluted using 7.0 $\mathrm{mL}$ distilled water and the absorbance was read after $2 \mathrm{hrs}$ at $765 \mathrm{~nm}$; the result was calculated as gallic acid equivalent [26].

Determination of Vitamin C (Ascorbic Acid): Vitamin C (Ascorbic acid) contents of the samples were determined by the 2,6-dicholorophenolindophenol titrimetric method as described by AOAC (1990). Two grams $(2 \mathrm{~g})$ of the honey sample was weighed and extracted in $5 \mathrm{~mL}$ of $20 \%$ metaphosphoric acid. A standard solution containing $50 \mathrm{mg} \mathrm{L}$-ascorbic acid dissolved in $90 \mathrm{~mL}$ of $20 \%$ metaphosphoric acid and made up to $100 \mathrm{~mL}$ with water was also prepared. Two milliliters $(2 \mathrm{~mL})$ each of the standard and sample were titrated with the 2,6-dicholorophenolindophenol solution until a faint pink end point lasting at least 10 to 15 seconds was observed. The vitamin $\mathrm{C}$ content was calculated as follows:

$$
\begin{aligned}
& \text { Vitamin C }(\mathrm{mg} / 100 \mathrm{~g})=\frac{\text { Titer value } \mathrm{x} \text { dye factor } \mathrm{x} 100}{\text { Weight of sample }} \\
& \text { Dye factor }(\mathrm{DF})=\frac{0.5}{\text { Standard Titer }}
\end{aligned}
$$

\section{Statistical Analysis}

The data obtained in the study were analysed statistically using ANOVA and student t-test (using GraphPad Instat Statistical Program). Differences between mean values were considered significant at values of $\mathrm{P}<0.05$.

\section{Results}

\section{Proximate composition}

The results of the proximate analysis of honey samples obtained from different location in the six states within the north east sub-region of Nigeria are presented in Table 1. The results showed no significant differences $(\mathrm{P}>0.05)$ between the samples for moisture, ash, fat and carbohydrate contents as well as the energy values of the honey samples from all the states. However, significant differences $(\mathrm{P}<0.05)$ in protein contents were observed between the honey samples. Samples from
Bauchi State showed significantly $(\mathrm{P}<0.05)$ higher protein contents $(1.04 \pm 0.04 \mathrm{~g} / 100 \mathrm{~g})$ when compared to samples from Adamawa $(0.50$ $\pm 0.10 \mathrm{~g} / 100 \mathrm{~g})$, Borno $(0.46 \pm 0.09 \mathrm{~g} / 100 \mathrm{~g})$ and Yobe $(0.55 \pm 0.22 \mathrm{~g} / 100$ g) States, but showed no significant difference $(\mathrm{P}>0.05)$ from the values obtained for samples from Gombe $(0.72 \pm 0.14 \mathrm{~g} / 100 \mathrm{~g})$ and Taraba States $(0.76 \pm 0.29 \mathrm{~g} / 100 \mathrm{~g})$. The protein contents of the honey samples from Gombe and Taraba States did not, however, differ significantly $(\mathrm{P}>0.05)$ from the values obtain for samples from Adamawa, Borno and Yobe States.

In general, the results for the eighteen honey samples from the sub-region (Table 2) showed that moisture contents ranged between 12.50 and $21.00 \mathrm{~g} / 100 \mathrm{~g}$ with an average value of $16.00 \pm 2.19 \mathrm{~g} / 00 \mathrm{~g}$. Ash contents varied from 0.28 to $0.60 \mathrm{~g} / 100 \mathrm{~g}$ with an average of $0.47 \pm$ $0.09 \mathrm{~g} / 100 \mathrm{~g}$. The protein contents ranged between 0.35 and $1.08 \mathrm{~g} / 100$ $\mathrm{g}$ with a mean of $0.67 \pm 0.25 \mathrm{~g} / 100 \mathrm{~g}$ while fat content lied between 0.10 and $0.50 \mathrm{~g} / 100 \mathrm{~g}$ with a mean of $0.29 \pm 0.11 \mathrm{~g} / 100 \mathrm{~g}$. Total carbohydrate contents and Energy values ranged from 77.60 to $86.20 \mathrm{~g} / 100 \mathrm{~g}$ and $1,323.10$ to $1,470.50 \mathrm{KJ} / 100 \mathrm{~g}$, with average values of $82.30 \pm 2.03 \mathrm{~g} / 100$ $\mathrm{g}$ and $1,401.33 \pm 33.71 \mathrm{KJ} / 100 \mathrm{~g}$, respectively.

\section{Sugar contents}

The results of sugar analysis of the honey samples are presented in Table 3. No significant differences $(P>0.05)$ in the fructose, glucose, fructose+glucose and reducing sugar contents were observed in samples from the six States of the sub-region. Similarly, no significant difference, $(\mathrm{P}>0.05)$ in both fructose/glucose ratio and glucose/water ratio were observed between samples from all the six States. However, the apparent sucrose contents of samples from Bauchi $(2.57 \pm 0.26$ $\mathrm{g} / 100 \mathrm{~g})$ Gombe $(2.54 \pm 0.97 \mathrm{~g} / 100 \mathrm{~g})$ and Yobe $(2.46 \pm 0.27 \mathrm{~g} / 100 \mathrm{~g})$ were statistically similar and significantly $(\mathrm{P}<0.05)$ higher than those for Adamawa $(1.62 \pm 0.40 \mathrm{~g} / 100 \mathrm{~g})$, Borno $(1.01 \pm 0.42 \mathrm{~g} / 100 \mathrm{~g})$ and Taraba $(1.01 \pm 0.33 \mathrm{~g} / 100 \mathrm{~g})$ States.

The results of the sugar analysis of all the eighteen (18) honey samples (Table 4) showed that the fructose contents varied between 37.68 and $40.31 \mathrm{~g} / 100 \mathrm{~g}$ with an average of $38.94 \pm 0.89 \mathrm{~g} / 100 \mathrm{~g}$. The glucose contents of the samples were within a range of 27.25 to $39.56 \mathrm{~g} / 100 \mathrm{~g}$ with a mean value of $31.65 \pm 2.27 \mathrm{~g} / 100 \mathrm{~g}$. The fructose contents of the samples were significantly $(\mathrm{P}<0.001)$ higher than the glucose contents. The fructose/glucose ratio and glucose/water ratio

\begin{tabular}{|c|c|c|c|c|c|c|}
\hline Parameter & Adamawa & Bauchi & Borno & Gombe & Taraba & Yobe \\
\hline Moisture (g/100g) & $15.83 \pm 0.58$ & $15.83 \pm 1.26$ & $16.67 \pm 4.25$ & $17.33 \pm 2.56$ & $15.00 \pm 2.78$ & $15.33 \pm 1.53$ \\
\hline Ash (g/100g) & $0.37 \pm 0.008$ & $0.54 \pm 0.11$ & $0.41 \pm 0.09$ & $0.48 \pm 0.05$ & $0.47 \pm 0.11$ & $0.52 \pm 0.02$ \\
\hline Protein (g/100g) & $0.50 a \pm 0.10$ & $1.04 b, c \pm 0.04$ & $0.46 a \pm 0.09$ & $0.72 a, c \pm 0.14$ & $0.76 a, c \pm 0.29$ & $0.55 a \pm 0.22$ \\
\hline Fats $(\mathrm{g} / 100 \mathrm{~g})$ & $0.20 \pm 0.10$ & $0.22 \pm 0.13$ & $0.40 \pm 0.10$ & $0.35 \pm 0.09$ & $0.32 \pm 0.08$ & $0.30 \pm 0.10$ \\
\hline Carbohydrate (g/100g) & $83.09 \pm 0.54$ & $82.20 \pm 1.22$ & $82.10 \pm 4.31$ & $81.10 \pm 2.40$ & $82.33 \pm 1.76$ & $83.00 \pm 1.31$ \\
\hline Energy $(\mathrm{KJ} / 100 \mathrm{~g})$ & $1,407.11 \pm 10.94$ & $1,405.06 \pm 18.04$ & $1,397.40 \pm 73.72$ & $1,383.23 \pm 39.09$ & $1,404.97 \pm 30.09$ & $1,410.20 \pm 24.43$ \\
\hline
\end{tabular}
were within the range of 1.00 to 1.45 and 1.59 to 2.75 with mean values

Values presented are mean $\pm S D$ of three determinations. Mean values with different superscript along a row are significantly different $(P<0.05)$ Table 1: Proximate Composition and Energy Values of Honey Samples from the Six States in Northeastern.

\begin{tabular}{|c|c|c|c|}
\hline Parameters & Mean \pm SD & $\begin{array}{c}\text { Range of values } \\
\text { (Min }- \text { Max) }\end{array}$ & $\begin{array}{c}\text { Samples outside Limits of Int'l Std. } \\
\text { of International Standard }\end{array}$ \\
\hline Moisture $(\mathrm{g} / 100 \mathrm{~g})$ & $16.00 \pm 2.19$ & $12.50-21.00$ & Not $>20 \mathrm{~g} / 100 \mathrm{~g}$ \\
\hline Ash $(\mathrm{g} / 100 \mathrm{~g})$ & $0.42 \pm 0.09$ & $0.28-0.60$ & $\leq 0.6 \mathrm{~g} / 100 \mathrm{~g}$ \\
\hline Protein $(\mathrm{g} / 100 \mathrm{~g})$ & $0.67 \pm 0.25$ & $0.35-1.08$ & No fixed limit \\
\hline Fat $(\mathrm{g} / 100 \mathrm{~g})$ & $0.29 \pm 0.11$ & $0.10-0.50$ & Nomple with $21 \mathrm{~g} / 100 \mathrm{~g}$ \\
\hline Carbohydrate $(\mathrm{g} / 100 \mathrm{~g})$ & $82.30 \pm 2.03$ & $77.60-86.20$ & No fixed limit \\
\hline Energy KJ/100g & $1401.33 \pm 33.71$ & $1323.10-1470.50$ & No fixed limit \\
\hline
\end{tabular}

Table 2: Proximate Composition and Energy Values of Eighteen (18) Honey Samples from Northeastern Nigeria 


\begin{tabular}{|c|c|c|c|c|c|c|}
\hline Parameter & Adamawa & Bauchi & Borno & Gombe & Taraba & Yobe \\
\hline Fructose $(\mathrm{g} / 100 \mathrm{~g})$ & $38.58 \pm 0.57$ & $39.02 \pm 0.82$ & $39.21 \pm 1.27$ & $39.06 \pm 1.13$ & $38.60 \pm 1.27$ & $39.15 \pm 0.86$ \\
\hline Glucose (g/100g) & $31.27 \pm 6.30$ & $31.81 \pm 6.74$ & $33.36 \pm 1.99$ & $30.27 \pm 1.37$ & $31.81 \pm 1.11$ & $31.37 \pm 1.79$ \\
\hline $\begin{array}{l}\text { Fructose + Glucose } \\
(\mathrm{g} / 100 \mathrm{~g})\end{array}$ & $69.85 \pm 2.18$ & $70.83 \pm 7.14$ & $72.57 \pm 1.86$ & $69.34 \pm 2.35$ & $70.41 \pm 1.27$ & $70.53 \pm 1.13$ \\
\hline $\begin{array}{l}\text { Reducing sugar } \\
(\mathrm{g} / 100 \mathrm{~g})\end{array}$ & $75.83 \pm 9.36$ & $75.26 \pm 13.71$ & $72.85 \pm 4.75$ & $69.56 \pm 0.99$ & $69.83 \pm 3.82$ & $71.05 \pm 2.63$ \\
\hline Sucrose $(g / 100 g)$ & $1.62^{\mathrm{a}} \pm 0.40$ & $2.57^{b} \pm 0.26$ & $1.01^{\mathrm{a}} \pm 0.42$ & $2.54^{b} \pm 0.97$ & $1.01^{\mathrm{a}} \pm 0.33$ & $2.46^{b} \pm 0.27$ \\
\hline $\begin{array}{c}\text { Fructose/Glucose } \\
\text { Ratio }\end{array}$ & $1.23 \pm 0.05$ & $1.26 \pm 0.23$ & $1.18 \pm 0.10$ & $1.29 \pm 0.04$ & $1.21 \pm 0.07$ & $1.25 \pm 0.10$ \\
\hline Glucose/water Ratio & $1.98 \pm 0.11$ & $2.04 \pm 0.61$ & $2.09 \pm 0.58$ & $1.77 \pm 0.26$ & $2.16 \pm 0.34$ & $2.05 \pm 0.09$ \\
\hline
\end{tabular}

values are presented as mean $\pm \mathrm{SD}$ of three determination values with different superscripts are along a row arare significantly different from each other $(\mathrm{P}<0.05)$ Table 3: Sugar Contents of Honey Samples from the Six States in Northeastern Nigeria.

\begin{tabular}{|c|c|c|c|}
\hline Parameters & Mean \pm SD & $\begin{array}{c}\text { Range of values } \\
\text { (Min-Max) }\end{array}$ & $\begin{array}{c}\text { Samples outside the Limits of } \\
\text { International Standards }\end{array}$ \\
\hline Fructose $(\mathrm{g} / 100 \mathrm{~g})$ & $38.94 \pm 0.89$ & $37.68-40.31$ & No fixed limit \\
\hline Glucose $(\mathrm{g} / 100 \mathrm{~g})$ & $31.65 \pm 2.27$ & $27.25-39.56$ & No fixed limit \\
\hline Fructose + Glucose $(\mathrm{g} / 100 \mathrm{~g})$ & $70.59 \pm 3.01$ & $66.70-79.08$ & Not $<60 \mathrm{~g} / 100 \mathrm{~g}$ \\
\hline Sucrose $(\mathrm{g} / 100 \mathrm{~g})$ & $1.84 \pm 0.79$ & $0.53-3.29$ & Not $>5 \mathrm{~g} / 100 \mathrm{~g}$ \\
\hline Fructose/Glucose Ratio & $1.24 \pm 0.10$ & $1.00-1.45$ & No fixed limit \\
\hline Glucose/Water Ratio & $2.01 \pm 0.35$ & $1.59-2.75$ & None \\
\hline
\end{tabular}

Table 4: Sugar Contents of Eighteen (18) Honey Samples from Northeastern Nigeria.

of $1.24 \pm 0.10$ and $2.01 \pm 0.35$, respectively. No significant difference ( $\mathrm{P}>0.05)$ was observed between the fructose/glucose and the glucose/ water ratios.

The sum of fructose and glucose (fructose+glucose) contents ranged between 66.70 and $79.08 \mathrm{~g} / 100 \mathrm{~g}$ with an average of $70.59 \pm$ $3.01 \mathrm{~g} / 100 \mathrm{~g}$ while the reducing sugar contents varied between 65.53 and $91.05 \mathrm{~g} / 100 \mathrm{~g}$ with an average of $72.40 \pm 6.65 \mathrm{~g} / 100 \mathrm{~g}$. There was no significant $(p>0.05)$ difference between the mean values of the fructose plus the glucose contents and the reducing sugar contents of the honey samples. The sucrose contents of the honey samples gave a range from 0.53 to $3.29 \mathrm{~g} / 100 \mathrm{~g}$ with a mean value of $1.84 \pm 0.79 \mathrm{~g} / 100 \mathrm{~g}$ and is significantly $(\mathrm{P}<0.001)$ lower than the fructose contents as well as the glucose contents.

\section{Vitamin C and Total Polyphenol Contents}

Table 5 shows the vitamin $\mathrm{C}$ and total polyphenol contents of the honey samples from the various States. The results indicate that there are no significant differences $(\mathrm{P}>0.05)$ in the values of these two parameters when comparisons are made between the samples from all the States. For the eighteen (18) samples studied the polyphenol and vitamin $\mathrm{C}$ contents showed ranges from 36.26 to $102.80 \mathrm{mgGAE} / 100 \mathrm{~g}$ and 13.86 to 27.32 with mean values of $65.31 \pm 19.50 \mathrm{mg} \mathrm{GAE} / 100 \mathrm{~g}$ and $21.15 \pm 3.99 \mathrm{mg} / 100 \mathrm{~g}$, respectively.

\section{Discussion}

The average moisture of the honey samples from all the States in Northeastern Nigeria were found to be within the limit of not more than $20.0 \mathrm{~g} / 100 \mathrm{~g}$ as prescribed by Codex Alimentarius Commission [27-29]. Most of the samples showed low moisture contents (average value $16.00 \pm 2.19 \mathrm{~g} / 100 \mathrm{~g}$ ), and only one sample exceeded the limit of $20.0 \mathrm{~g} / 100 \mathrm{~g}$ established by international norms. The values fall within the range of moisture contents reported by White and Doner [4] for 490 samples of floral honey having a range from 13.4 to $22.9 \mathrm{~g} / 100 \mathrm{~g}$ and an average value of $17.2 \pm 1.46 \mathrm{~g} / 100 \mathrm{~g}$. These results are similar to results of other researchers $[8,10,30,31]$.

Moisture content is an important quality parameter, important above all for honey shelf-life [32,33]. It is the only composition criterion which as a part of honey standard has to be fulfilled in world honey trade [34]. The significance of moisture in honey derives from the fact that there is a relationship between honey water content and yeast count; at $17.0 \mathrm{~g} / 100 \mathrm{~g}$ moisture (humidity) there is very minimal fermentation danger due to very low yeast count [32]. Thus, honey having high water content is more likely to ferment [34]. A maximum value of $20.0 \mathrm{~g} / 100$ g was established by the Codex Alimentarius Commission and EU Commission as the international standard for honey moisture contents.

The ash contents of honey obtained in this study were all within the limits of $<0.6 \mathrm{~g} / 100 \mathrm{~g}$ specified by international norms $[1,2]$. There were no significant differences between the ash contents of the sample from all the States in the sub-region. The results of the ash contents are similar to those reported for honey samples from southern part of Nigeria [10] as well as values reported for samples from Argentina, Spain and Turkey [8]; northern region of Bangladesh [35]; different areas of Pakistan [36,37] and Algeria [30].

The Ash content of honey is also a parameter that is used in determining the floral origin of honeys. Thus, by reference to the Codex Alimentarius Standards, all the honeys analysed in this study correspond to nectar honey since their ash contents falls within the values of $<0.6 \%$. The ash contents of honeys represent their mineral and trace element contents. According to Bogdanov [33], blossom honeys have a mineral content mostly between 0.1 and $0.3 \%$ while that of honeydew honeys can reach $1.0 \%$ of the total. Several investigations have shown that the trace element content of honey depends mainly on the botanical origin of honey; i.e. light blossom honeys have low contents than dark honeys such as honeydew, chestnut and heather honeys [38,39].

The protein contents of honey samples from some of the States of the northeast were significantly $(\mathrm{P}<0.05)$ different. The values obtained in this study are similar to those reported by Khalil [35], for five different brands of unifloral honey from the northern region of Bangladesh, which ranged between 0.655 and $0.744 \mathrm{~g} / 100 \mathrm{~g}$. The amount of nitrogen in honey is generally low, in average of about $0.04 \%$ although it may reach up to $0.1 \%[4,40]$. It was also reported that of the total amount of Nitrogen in honey only $40-65 \%$ is in protein, the remaining part of 


\begin{tabular}{|c|c|c|c|c|c|}
\hline Parameter & Adamawa & Bauchi & Borno & Gombe & Yaraba \\
\hline $\begin{array}{c}\text { Total Polyphenol } \\
\text { (mg/100g) }\end{array}$ & $72.06 \pm 4.99$ & $72.41 \pm 26.45$ & $64.08 \pm 16.17$ & $62.56 \pm 27.35$ & $60.94 \pm 34.99$ \\
\hline Vitamin C (mg/100g) & $20.68 \pm 2.83$ & $18.52 \pm 5.46$ & $19.76 \pm 2.55$ & $21.61 \pm 4.82$ & $20.84 \pm 4.42$ \\
\hline
\end{tabular}

Values are presented as Mean \pm SD of three determinations. Values along rows are not significantly different $(P>0.05)$ for all the States.

Table 5: Total Polyphenol and Vitamin C Contents of Honey Samples from States of Northeastern Nigeria.

total nitrogen resides in substances other than protein, such as amino acids. About 8 to 11 proteins have been found in various honeys but only four (4) proteins are common to all honeys and these four (4) proteins common to all appear to originate from the honey bee rather than from nectar. The honey proteins are mainly in the form of enzymes [40]. The honey bees add different enzymes during the process of honey ripening. The enzymes added include diastase (amylase), which digest starch to maltose and is relatively stable to heat and storage, and invertase (saccharase or $\alpha$-glucosidase), which catalyses the conversion of sucrose to glucose and fructose. The invertase also catalyses many other sugar conversions and is mainly responsible for the sugar patterns of honey. Glucose oxidase and catalase are two other enzymes added by the honey bee, which regulate the production of hydrogen peroxide $\mathrm{H} 2 \mathrm{O} 2$; the $\mathrm{H} 2 \mathrm{O} 2$ serve as one of the anti-bacterial factor in honey.

The significant differences observed between the total protein contents of honey samples from some of the States within the subregion may be ascribed to differences in the botanical origin of honey since it was reported that the diastase and the invertase enzymes varied in wide limits depending on the botanical origin of honey [41]. Bosi and Battalglini [42] had reported protein contents of honey varying between 0.01 to $0.04 \mathrm{~g} / 100 \mathrm{~g}$ with proline, lysine, phenylalanine, aspartic acid and glutamic acid as the most widely detected amino acids.

The fat contents of the honey samples investigated in this study fall within the range of 0.1 to $0.5 \mathrm{~g} / 100 \mathrm{~g}$. Reports indicating that honey contains little or no fat are available in the literature [43,44], but the presence of free fatty acids like palmitic, oleic and linolenic acids have been reported in white clover honey. In a biochemical analysis of five different brands of unifloral honey available in the northern region of Bangladesh, Khalil [35] reported total fat contents in the range of 0.134 to $0.146 \mathrm{~g} / 100 \mathrm{~g}$; thus, indicating that honey contains very little amount of lipid and therefore not considered a good source of lipid.

The total carbohydrate contents of the honey samples from all the States were not significantly different from each other; this corresponds to the findings of others scientists [35-37]. Carbohydrates are the main constituents of honey comprising about $95 \%$ of honey dry weight. The monosaccharides, fructose and glucose, are the main sugars found in honey; these hexoses are products of the hydrolysis of sucrose. In addition to these sugars, 25 others have been detected in honey samples $[45,46]$. The principal oligosaccharides in blossom honey include the disaccharides sucrose, maltose, turanose, erlose, etc. On the other hand, honeydew honeys also contain the disaccharides melezitose and raffinose; with trace amounts of tetra and pentasaccharides also isolated [4].

The average energy value of the honey samples from all the States ranged between $1383.23 \pm 39.09$ and $1410.20 \pm 24.43 \mathrm{KJ} / 100$ g. Honey is primarily a high energy carbohydrate food and the honey sugars are easily digestible sugars similar to those found in many fruits (White and Doner, 1980). For this reason honey is regarded as a good food for both infants and adults. Blasa [47] had reported caloric value of about $303 \mathrm{kcal} / 100 \mathrm{~g}$ of honey.

The reducing sugar contents of the samples used in this study had average value of $72.40 \pm 6.65 \mathrm{~g} / 100 \mathrm{~g}$, the values obtained in this study are similar to the values reported for honeys from Bangladesh [35],
Pakistan [36], Argentina and Turkey [8] and Venezuela [48].

The fructose contents of the honey samples analysed in this study varied between 37.68 to $40.31 \mathrm{~g} / 100 \mathrm{~g}$ with an average of $38.94 \pm$ $0.40 \mathrm{~g} / 100 \mathrm{~g}$. The average fructose contents for the samples from the different States within the sub-region were not significantly different from each other and they all fall within the range of values reported by other scientists $[4,9,30,31,49]$.

In a similar manner, the glucose contents of the honey samples obtained from the various locations in the different States of the subregion were not significantly different from each other. The glucose contents of the samples which varied from 27.25 to $39.56 \mathrm{~g} / 100 \mathrm{~g}$ with an average of $31.65 \pm 2.79 \mathrm{~g} / 100 \mathrm{~g}$ were significantly $(\mathrm{P}<0.05)$ lower than the fructose contents. This observation shows that fructose is the major sugar in all the samples analysed and, it is in agreement with the earlier observation of White and Doner [4]. Fructose and glucose are the dominant sugar types in honeys, which although no limits have been fixed for their individual values, their sum (Fructose+glucose) has been fixed at a value of $\geq 60 \mathrm{~g} / 100 \mathrm{~g}$ as one of the requirements of the international standard for honey established by Codex Alimentarius Commission. The sum of fructose and glucose for the honey samples, used in this study, indicates that samples have their values corresponding to the limit required by the international norms; i.e., $60 \mathrm{~g} / 100 \mathrm{~g}$ and above. According to White and Doner [4] the dominance of fructose over glucose is one way in which honey differs from commercial invert sugar. Generally, the sugar spectrum of honey depends upon the sugars present in the nectar and the enzymes present in the bee and nectar $[4,33,49]$. Fructose and glucose constitute the primary sugars in all honey samples, and in honey of good quality the fructose content should exceed that of glucose [49].

In addition to the sum of fructose and glucose, other important factors that relate to honey quality include the fructose/glucose ratio and glucose/water ratio. In this study, the fructose/glucose ratio and glucose/water ratio fall in the range of 1.00 to 1.45 and 1.59 to 2.75 with average values of $1.24 \pm 0.10$ and $2.01 \pm 0.35$, respectively. Fructose/ glucose ratio indicates the ability of honey to crystallize. White and Doner [4] stated that even though honey has less glucose than fructose, it is the glucose that crystallizes when honey granulates because it is less soluble in water than fructose. When the fructose/glucose ratio is high, honey remains liquid. Honey crystallization is slower when the fructose/glucose ratio is more than 1.3 and it is faster when the ratio is below 1.0 [30]. However, because honey contains others sugars (sucrose, maltose, turanose, etc) and insoluble substances (like dextrin, colloids, etc) which can influence the crystallization process, the glucose/water $(\mathrm{G} / \mathrm{W})$ ratio is considered more appropriate than the fructose/glucose (F/G) ratio for the prediction of honey crystallization. It has been stated that when the glucose/water ratio is $<1.3$ honey crystallization is very slow or even zero, and it is complete and rapid when the ratio is $>2.0$ [30]. Glucose, which is a major sugar in honey, can spontaneously crystallize from honey solutions in the form of its monohydrate [4]. This sometimes occurs when the moisture level in honey is allowed to drop below a certain level; i.e., when the moisture content is very low. It was stated earlier on that honey samples with $(\mathrm{G} / \mathrm{W})$ ratio of $<1.7$ are 
considered non-granulating while samples with ratios of $\geq 2.1$ predicts rapid granulation. Also, according to Manikis and Thrasivoulou [50], while glucose levels is a useful indicator of honey granulation, the $\mathrm{G} / \mathrm{W}$ ratio appears to be one of the most effective indicator for predicting granulation tendencies in honey samples. Thus, G/W ratio may be used both to predict and control granulation tendencies in honeys.

The international norm established by the Codex Alimentarius Commission requires that a good quality honey should not contain more than $5 \mathrm{~g} / 100 \mathrm{~g}$ sucrose. The apparent sucrose contents of the honey samples studied were in the range of 0.53 to 3.29 with an average of $1.84 \pm 0.79 \mathrm{~g} / 100 \mathrm{~g}$. The values obtained for sucrose contents of the honey samples were all within the limits of international standards. According to White and Doner [4] even though honey contains an active sucrose splitting enzyme (sucrase, glucosidase), the sucrose level in honey never reaches zero. The sucrose contents obtained in this investigation are within the range of values reported for Argentine and Turkish [8], Venezuelan [48], American [4], Algerian [31], Pakistani [49] and Spanish [51] honeys.

The total polyphenol and vitamin C contents in the honey samples were not significantly different among the samples. The polyphenol contents of the honey samples from this sub-region varied between 36.26 and $102.80 \mathrm{mgGAE} / 100 \mathrm{~g}$ with an average of $65.31 \pm 19.50$ mgGAE/100 g, while vitamin $C$ contents were observed to be within the range of 13.89 and $27.32 \mathrm{mg} / 100 \mathrm{~g}$ with an average of $21.15 \pm 3.99$ $\mathrm{mg} / 100 \mathrm{~g}$. A variety of phytochemicals, as well as other substances including organic acids, vitamins, and enzymes; some of which may serve as sources of dietary antioxidant $[6,52]$ are known to occur in honeys.

The range and average values of total phenolic contents observed for the honey samples used in this study are similar to those reported by Vit [48] for Venezuelan Apis Mellifera honeys (38.15 to 182.10 $\mathrm{mgGAE} / 100 \mathrm{~g}$, with an average of $93.50 \pm 51.62 \mathrm{mgGAE} / 100 \mathrm{~g})$. The values of phenolic contents in this study are, however, higher $(\mathrm{P}<0.05)$ than those reported by Adetuyi [22] for Apis Mellifera honey samples in Owo community, Ondo State in southwest Nigeria (0.75 to 2.85 mgGAE/100 g). The phenolic contents obtained in this study are also higher $(\mathrm{P}<0.05)$ than those observed in selected Czech honey; $3.92 \pm$ 0.13 to $16.71 \mathrm{mgGAE} / 100 \mathrm{~g}$ [53] and in some honeys from Poland, 7.17 \pm 0.13 to $20.16 \pm 1.68 \mathrm{mgGAE} / 100 \mathrm{~g}$ [54]. It was earlier reported that, in honey samples from Burkina Faso, total phenolic contents varied from 32.59 to $114.75 \mathrm{mgGAE} / 100 \mathrm{~g}$ with a mean of $74.38 \pm 20.54 \mathrm{mgGAE} / 100$ $\mathrm{g}$ [55]. Phenols are reported to have antioxidant capacities that are much stronger than those of vitamins C and E [56]. According to Blasa [47] raw honey contains copious amounts of compounds such as flavonoids and other polyphenols which may function as antioxidants. Honey polyphenols are said to originate from nectar, pollen or propolis [57].

The presence of vitamin C (L-ascobic acid in the honey samples used in this study is in agreement with earlier reports of other scientists $[48,58,59]$. It was reported that the honey of Apis mellifera has a low concentration of vitamin C, less than $5 \mathrm{mg} / 100 \mathrm{~g}$ [40] and concentration of $2.5 \mathrm{mg}$ vitamin $\mathrm{C}$ per $100 \mathrm{~g}$ honey is found in the literature [60]. However, higher concentrations of the vitamin have been reported in recent times. Matei [58] reported vitamin $\mathrm{C}$ contents ranging from 226 to $296 \mathrm{mg} / 100 \mathrm{~g}$ for floral honeys in Romania. In addition, vitamin C concentrations ranging between 37.22 to $378.30 \mathrm{mg} / 100 \mathrm{~g}$ were reported for various types of honeys from different locations in Bosnia Herzegovina, with the higher concentrations, in forest honeys [59]. In another report, Vit [48] found that vitamin C contents varied between 12.86 and $37.05 \mathrm{mg} / 100 \mathrm{~g}$ in Venezuelan honeys. The vitamin C contents obtained for the honey samples used in this study are within the range reported by Vit [48], but much lowers than the values reported by Matei $[58,59]$. Honey contains ascorbic acid because most flowers on which the bees forage contain this vitamin which serves as an antioxidant in addition to many other functions. Indeed, it has been shown that antioxidant activity of honey, which depends on its botanical origin, is related to its vitamin $\mathrm{C}$ contents; i.e., the content of vitamin $\mathrm{C}$ has a significant impact on total antioxidant activity of honey [59].

\section{Conclusion}

The values of quality parameters for all the honey samples studied coincide with those specified by the international honey regulations. The honey samples are also rich in phenolic and vitamin $\mathrm{C}$ contents which confer good antioxidant properties in honey.

\section{References}

1. Codex Alimentarius Commission (2001a) Codex Standard for Honey, FAO, Rome. Alinorm 1: 19-26.

2. Codex Alimentarius Commission (2001b) Codex Standard 12, Revised Codex Standard for Honey, Standards and Standard Methods 11.

3. James OO, Mesubi MA, Usman LA, Yeye SO, Ajanaku KO, et al. (2009) Physical characteristics of some honey samples from North-Central Nigeria. International Journal of Physical Sciences 4: $464-470$.

4. White JW, Doner LW (1980) Honey composition and properties: Beekeeping in the United States. Agriculture Handbook No. 335, Revised October 82-91.

5. Jeffrey AE, Echazarreta CM (1996) Medical uses of honey. Revista Biomedica 7: 43-49.

6. Gheldof N, Engeseth NJ (2002) Antioxidant capacity of honeys from various floral sources based on the determination of oxygen radical absorbance capacity and inhibition of in vitro lipoprotein oxidation in human serum samples. J Agric Food Chem 50: 3050-3055.

7. National Honey Board (2003) Honey: Health and Therapeutic Qualities. National Honey Board, Longman 28.

8. Cantarelli MA, Pellerano RG, Marchevsky EJ, Camina (2008) Quality of honey from Argentina: study of chemical composition and trace elements. The Journal of the Argentine Chemical Society 96: 33-41.

9. Ciappini MC, Gatti MB, Di Vito MV, Gattuso S, Gattuso M (2008) Characterization of different floral origins honey samples from Santa Fe (Argentina) by palynological, physicochemical and sensory data. Apiacta 43: 25-36.

10. Omafuvbe BO, Akanbi OO (2009) Microbiological and physico-chemical properties of some commercial Nigerian honey. African Journal of Microbiology Research 3: 891-896.

11. Ebenezer IO, Olubenga MT (2010) Pollen characterization of honey samples from North Central Nigeria. Journal of Biological Sciences 10: 43-47.

12. Ojeleye B (1999) Foundation of Beekeeping in the Tropics. CEBRAD Press Ltd., Ibadan 225.

13. Ayoade JAA (1997) Beekeeping Among the Tivs. The Nigerian Field 42: 31-36

14. Malaka SLO, Fasasi KA (2002) Beekeeping in Lagos and its Environs. Occasional Publication of Entomological Society of Nigeria 34: 92-97.

15. Ojeleye B (1992) Foundation of Beekeeping in the Tropics. CEBRAD Press Ltd., Ibadan, 225.

16. Lawal RA, Lawal AK, Adekalu JB (2009) Physico-chemical studies on adulteration of honey in Nigeria. Pak J Biol Sci 12: 1080-1084.

17. Ja'afar-Furo MR, Suleiman A, El-Sahab YH (2006) A Comparative analysis of beekeeping and crop production in adamawa State, Nigeria. Apiacta 41: 44-53.

18. Oluwatusin FM (2008) Cost and returns in modern beekeeping for honey production in Nigeria. Pakistan Journal of Social Sciences 5: 310-315.

19. Ja'afar-Furo MR (2007) Appraising the perception of farming communities towards adoption of apiculture as a viable source of income in Adamawa State, Nigeria. Apiacta 42: 1-15. 
Citation: Buba F, Gidado A, Shugaba A (2013) Analysis of Biochemical Composition of Honey Samples from North-East Nigeria. Biochem Anal Biochem 2: 139. doi: 10.4172/2161-1009.1000139

20. Iloeje NP (1976) A New Geography of Nigeria. Longman Nigeria Limited

21. Adebiyi FM, Akpan I, Obianjuwa EI, Olaniyi HB (2004) Chemical/physical characterization of Nigerian honey. Pakistan Journal of Nutrition 3: 278-281.

22. Adetuyi FO, Ibrahim TA, Ojei J, Ogundahunsi GA (2009) Total phenol, tocopherol and antibacterial quality of honey Apis mellifera sold in Owo community, Ondo State, Nigeria. African Journal of Biotechnology 8: 1305-1309.

23. AOAC (1990) Food composition, additives and natural contaminants. In: Official Methods of Analysis. Helrich, K. (ed). Association of Official Analytical Chemists International 2, 15th Edition, Arlington, VA, USA.

24. AOAC (2000) Sugars and sugar products. In: Official Methods of Analysis. Horwitz, W. (ed.). Association of Official Analytical Chemists International, Vol. 2 No. 44, 16th Edition. Washington, DC $22-33$.

25. Kacaniova M, Vukovic N, Bobkova A, Fikselova M, Rovna K, et al. (2011) Antimicrobial and antiradical activity of Slovakian honeydew honey samples. Journal of Microbiology, Biotechnology and Food Sciences 1: 354-368.

26. Igbal S, Bhanger MI, Anwar F (2004) Antioxidant Properties and Components of Some Commercially Available Varieties of Rice Bran in Pakistan. Journal of Food Chemistry 93: 265-272.

27. Codex Alimentarius Commission (1998) Draft Revised Standard for Honey at Step 6 of the Codex Procedure. CX 5/10.2, CL 1998/12-S.

28. Codex Alimentarius Commission (2001b) Codex Standard 12, Revised Codex Standard for Honey, Standards and Standard Methods 11.

29. EU Council (2002) Council Directive 2001/110/EC of 20 December 2001 Relating to Honey. Official Journal of the European Communities L 10: 47-52.

30. Amir Y, Yesli A, Bengana M, Sadoudi R, Amrouche T (2010) Physico-chemical and microbiological assessment of honey from Algeria. Electronic Journal of Environmental, Agricultural and Food Chemistry 9: 1485-1494.

31. Makhloufi C, Schweitzer P, Azouzi B, Oddo LP, Choukri A, et al. (2007) Some properties of Algerian honey. Apiacta 42: 73-80.

32. Bogdanov S (2009a) Physical properties of honey. In: Book of Honey, Chapter 4. Bee Product Science.

33. Bogdanov S (2009b) Honey Composition. In: Book of Honey, Chapter 5. Bee Product Science.

34. Bogdanov S, Lüllmann C, Martin P, Von Der Ohe W, Russmann H, et al. (1999) Honey quality, methods of analysis and international regulatory standards: review of the work of the international honey commission, Bee World 80: 61-69.

35. Khalil MI, Motallib MA, Anisuzzaman ASM, Sathi ZS, Hye MA, et al. (2001) Biochemical analysis of different brands of unifloral honey available at the Northern region of bangladesh. The Journal of Medical Sciences 1: 385-388.

36. Kamal A, Raza S, Rashid N, Hameed T, Gilani M, et al. (2002) Comparative study of honey Collected from different flora of Pakistan. Online Journal of Biological Sciences 2: 626-627.

37. Iftikhar F, Masood MA, Waghchoure ES (2011) Comparison of Apis cerana, Apis dorsata, Apis florea and Apis mellifera honey from different areas of Pakistan. Asian Journal of Experimental Biological Science 2: 399-403.

38. Feller-Demalsy MJ, Vincent B, Beaulieu F (1989) Mineral content and geographical origin of Canadian honeys. Apidologie 20: 77-91.

39. González-Miret ML, Terrab A, Hernanz D, Fernández-Recamales MA, Heredia FJ (2005) Multivariate correlation between color and mineral composition of honeys and by their botanical origin. J Agric Food Chem 53: 2574-2580.

40. White JW (1975) Physical characteristics of honey. In: Crane, E. (ed.), Honey, a Comprehensive Survey, Hienemann, London, Uk 207-239.

41. Oddo LP, Piazza MG, Pulcini P (1999) Invertase activity in Honey. Apidologie 30: 57- 65 .

42. Bosi G, Battalglini M (1978) Gas chromatographic analysis of free and protein amino acids in some unifloral honeys. Journal of Apicultural Research 17: 152-66.

Citation: Buba F, Gidado A, Shugaba A (2013) Analysis of Biochemical Composition of Honey Samples from North-East Nigeria. Biochem Anal Biochem 2: 139. doi: 10.4172/2161-1009.1000139
43. Tan ST, Holand PT, Wilkins AL, Molan PC (1988) Extractives from New Zealand honeys. Journal of Agricultural and Food Chemistry 36: 453-460.

44. Singh N, Kuar Bath P (1997) Quality evaluation of different types of Indian Honey. Food Chemistry 58: 129-133.

45. Doner LW (1977) The sugars of honey--a review. J Sci Food Agric 28: 443-456

46. Siddiqui IR (1970) The sugars of honey. Advances in Carbohydrate Chemistry and Biochemistry 25: 285-309.

47. Blassa M, Candracci M, Accorsi A, Piacentini MP, Albertini MC, et al. (2006) Raw Mellefiori honey is packed full of antioxidants. Food Chemistry 97: 217222.

48. Vit P, Rodríguez-Malaver A, Roubik DW, Moreno E, Souza BA, et al. (2009) Expanded parameters to assess the quality of honey from Venezuelan bees (Apis mellifera). Journal of ApiProduct and ApiMedical Science 1: 72-81.

49. Zafar A, Safdar M, Siddiqui N, Mumtaz A, Hameed T, et al. (2008) Chemica analysis and sensory evaluation of branded honey collected from Islamabad and Rawalpindi market. Journal of Agricultural Research 2: 86-91.

50. Manikis I, Thrasivoulou A (2001) Relation of Physicochemical Characteristics of Honey and the Crystallization Sensitive Parameters. Apiacta 36: 106-112.

51. Cavia MM, Fernández-Muiño MA, Alonso-Torre SR, Moreno G, Mato I, et al (2006) An Attempt to Establish Reliable "Best Before" Dates for Honeys Originating in both Continental and Oceanic Climates. Apiacta 41: 86-98.

52. Gheldof N, Wang XH, Engeseth NJ (2002) Identification and quantification of antioxidant components of honeys from various floral sources. J Agric Food Chem 50: 5870-5877.

53. Lachman J, Hejtmankova A, Sykora J, Karban J, Orsak M, et al. (2010) Contents of major phenolic and flavanoid antioxidants in selected Czech honey. Czech Journal of Food Science 28: 412-426.

54. Kaskoniene V, Maruska A, Kornysova O, Charezun N, Ligor M, et al. (2009) Quantitative and qualitative determination of phenolic compounds in honey. Chemine Technologija Nr 3: 74-80.

55. Meda A, Lamien CE, Romito M, Millogo J, Nacoulma OG (2005) Determination of the total phenolic, flavonoid and proline contents in Burkina Fasan honey, as well as their radical scavenging activity. Food Chemistry 91: 571-577.

56. Oboh G (2005) Effect of blanching on the antioxidant property of some tropical green leafy vegetables. Technology 38: 513-517.

57. Makawi SZA, Gadkariem EA, Ayoub SMH (2009) Determination of antioxidant flavonoids in Sudanese honey samples by Solid Phase Extraction and High Performance Liquid Chromatography. Electronic Journal of Chemistry 6 429-437.

58. Matei N, Birghila S, Dobrinas S, Capota P (2004) Determination of C vitamin and some essential trace elements $(\mathrm{Ni}, \mathrm{Mn}, \mathrm{Fe}, \mathrm{Cr})$ in bee products. Acta Chimica Slovania 51: 169 -175.

59. Kesic A, Mazalovic M, Crnkic A, Catovic B, Hadzidedic S, et al. (2009) The Influence of L-Ascorbic acid content total antioxidant activity of bee honey. European Journal of Scientific Research 32: 95-101.

60. Bogdanov S, Jurendic T, Sieber R, Gallmann P (2008) Honey for nutrition and health: a review. J Am Coll Nutr 27: 677-689. 